\title{
Vardagens kontraktualisering Om individuella genomförandeplaner i äldreomsorgen
}

\section{DAVID HEDLUND}

Individuella genomförandeplaner är en typ av plan på individnivå som blivit vanliga inom välfärdssektorn under de senaste femton åren. I den här artikeln betraktas individuella genomförandeplaner som ett försök att detaljreglera och "kontraktualisera" den vardagshjälp som tillhandahaills inom äldreomsorgen.

Studien visar att de skillnader som finns mellan olika planers form och innehäl inte fängar olikheter i omsorgstagarens behov och att det finns en skillnad mellan den omsorg som beskrivs $i$ dokumenten och den omsorg som faktiskt utförs.

\section{Inledning}

Syftet med den här artikeln är dels att uppmärksamma och teoretisera om fenomenet planer på individnivå inom omsorgen om äldre, dels att studera de intentioner som ligger bakom och den praxis som bildas i den form av planer på individnivå - individuella genomförandeplaner (IGP) - som för närvarande används inom äldreomsorgen.

David Hedlund är doktorand vid Vårdalinstitutet och Socialhögskolan, Lunds universitet.

\section{Planer på individnivå som} fenomen inom omsorgen om äldre

Planer på individnivå har blivit allt vanligare inom olika välfärdsområden under de senaste 15 åren (Johansson, 2006). Inom omsorgen om äldre är omsorgsplan, omvårdnadsplan, vårdplan, individuell genomförandeplan, individuell handlingsplan, serviceplan, boendeplan, vård- och omsorgsplan, habiliteringsplan, rehabiliteringsplan, insatsplan, samordnad individuell plan exempel på olika typer av planer på 
individnivå som förekommer i den samtida omsorgen om äldre. Hur utbredd användningen är av de olika typerna av planer på individnivå som räknades upp ovan framgår inte av den nationella statistiken. Myndigheten för Vårdanalys (2013) nationella kartläggning av olika arbetsformer i äldreomsorgen ger emellertid en indikation om att den typ av planer på individnivå som står i fokus i denna artikels andra del - individuella genomförandeplaner - används i merparten av landets kommuner. Följaktligen kan det antas att en inte oväsentlig andel av de 219700 medborgare som enligt Socialstyrelsen (2014) år 2013 hade beslut om hemtjänst också har någon form av individuell genomförandeplan.

När individuella genomförandeplaner föreslogs i Bemötandeutredningen (SOU 1997:170) förordade utredningen att de skulle lagstadgas. Motiveringen var att planerna bedömes vara en åtgärd som tillsammans med införandet av kontaktpersoner skulle stärka medborgares möjlighet till inflytande och råda bot på de brister i bemötande och inflytande som uppmärksammats inom äldreomsorgen. Planerna skulle enligt Bemötandeutredningen ses som en "överenskommelse mellan den enskilde och de/dem som på socialtjänstens uppdrag svarar för att den begärda individuella planen upprättas" (s. 157). Bemötandeutredningens förslag om ett lagstadgande antogs inte och individuella genomförandeplaner fick en juridisk status som allmänt råd. I samband med Värdighetsutredningen (SOU 2008:51) återaktualiserades frågan om att ändra de individuella genomförandeplanernas juridiska status från ett allmänt råd till lag. Regeringens bedömning i den efterföljande propositionen (prop. 2009/10:116) var att de individuella planerna visserligen var att betrakta som ett verktyg för att skapa inflytande för den äldre men att den juridiska statusen även fortsättningsvis ska vara ett allmänt råd. I Socialstyrelsens $(2006,2010,2014)$ allmänna råd och handböcker beskrivs individuella genomförandeplanerna som ett dokument som ska visa att medborgaren haft inflytande, redogöra för det konkreta genomförandet av vården- och omsorgen samt främja ett målinriktat arbete genom att specificera frågor om var, när och hur insatsen praktiskt ska genomföras.

\section{Från undantagskontrakt till individuell genomförandeplan}

Även om individuella genomförandeplaner presenterades som en nyhet som utlovade en lösning på uppmärksammade problem i Bemötandeutredningen så visar den begränsade forskning som finns på temat att det förekommit likartade planer i omsorgen om äldre i åtminstone tre olika samhälls- och organiseringskontexter. Det första sammanhanget beskrivs i Gaunts (1996) studie om hur omsorgen om äldre under medeltiden och i bondesamhället organiserades i överlåtelse- och undantagssystem. Systemen byggde på att bonden, oftast i god tid innan en stundande pensionering, med stöd av landskapslagar och senare landslagen via det förrättande tinget tecknade ett överlåtelse- eller undantagskontrakt. I kontrakten, som kunde vara mycket detaljerade angående vad respektive part skulle få i 
utbyte, överlät jordbrukaren sin egendom till släktingar eller någon annan i utbyte mot tryggad försörjning och omsorg under ålderdomen. Givet olikheter i hjälpens karaktär och sammanhang representerar kontrakten ett försök från samhället att reglera hjälp till äldre genom detaljerade överenskommelser.

Det andra sammanhanget beskrivs i Renström Törnbloms (1988) rapport om dokumentation inom de olika stadsdelsförvaltningarnas socialtjänstverksamheter i Stockholm stad under 1980-talet. Rapporten visar att det i de olika stadsdelsförvaltningars äldreomsorg fanns flera olika dokumentationsformer. Bland dessa dokumentationsformer nämns tre dokumentationsformer, "arbetskort", "överenskommelser" och "handlingsplaner", som utifrån Renström Törnbloms (1988) kortfattade beskrivning har påfallande likheter med individuella genomförandeplaner.

Det tredje sammanhanget är där äldreomsorgen enligt Meagher \& Szebehely (2013) organiserats efter ideal från New Public Management (NPM) och fria marknader. I detta sammanhang omnämns det som officiellt kallas individuella genomförandeplaner bland annat som "arbetsplan" (Hjalmarson, 2006), "serviceplan" (Löfström, 2007), "handlingsplan" (Blomberg \& Petersson, 2011).

\section{En materialisering av samhällskontraktet}

Inom äldreomsorgen har planer på individnivå alltså en lång historia där dokumentet - planen - fyllt en funktion av att beskriva och reglera relationen mellan den enskilde individen och omsorgsgivaren. Det tycks alltså, tvärtemot den slutsats som dras av Blomberg \& Petersson (2010) om att styrningsideal från NPM medfört att relationen mellan myndigheten och medborgare inom äldreomsorgen allt mer kommit att betraktas som en kontraktslig relation, finnas en lång tradition av att kontraktsliggörande $\mathrm{i}$ organiseringen av omsorgen om äldre.

Idén om ett sorts kontrakt mellan enskilda individer och det organiserade samhället har uttryckts av tänkare ända sedan antiken och har återkommande varit en del av politiska lösningar för att organisera samhällen och manifesterats $i$ överenskommelser där de inblandade parterna förpliktigat sig att utbyta och respektera så väl immateriella som materiella resurser och rättigheter (Baker, 1960).

När det kommer till planer på individnivå inom omsorgen om äldre så har utbytet av resurser och rättigheter sett något olika ut inom ramen för de tre samhälls- och organiseringskontexter som beskrivits ovan. I de överlåtelse- och undantagssystem som Gaunt (1996) beskriver, var utbytet av resurser och rättigheter explicit och direkt. I de två senare sammanhangen - byråkratin och marknaden - sker utbytet av resurser och rättigheter (och skyldigheter) för det stora flertalet av medborgarna under merparten av livet implicit och indirekt via det omfördelande, universella och behovsbaserade välfärdssystemet. I samband med ålderdomen antar emellertid utbytet även $i$ välfärdssamhället en mer explicit och direkt form genom att utbytet blir föremål för en nedtecknad beskriv- 
ning i form av beslut och dokumentationen. Utifrån detta kommer jag i denna artikel att betrakta genomförandeplaner på individnivå som fenomen i omsorgen om äldre, representerande en materialisering av ett samhällskontrakt. Jag tar alltså fasta på att tillämpandet av planer på individnivå inom omsorgen om äldre överensstämmer med vad som är väsentliga delar av kontraktsliga förfaranden. Med väsentliga delar menas här att planer på individnivå dels innehåller vad Johansson (2011) beskriver som ett juridifieringstänkande, vad Hirdman (2010) benämner som ett planeringstänkande och vad Ferraris (2013) betecknar som en dokumenteringstänkande. De ovan exemplifierade planerna på individnivå inom omsorgen om äldre har alla intentionen att vara juridiskt, framåtreglerande, dokumenterade överenskommelser om relationen mellan individ och omsorgsgivare i samband med organiserandet och genomförandet av omsorg. Om de kursiverade begreppen tas som någon sorts väsentliga beståndsdelar i idén om ett kontraktsliggörande har olika typer av planer på individnivå, oavsett vilket av de ovan exemplifierade samhälls- och organiseringskontexter de upprättas inom, representerat en materialisering av samhällskontraktet (jfr Johansson, 2006).

\section{Materialisering med individuella genomförandeplaner som exempel}

Den typ av planer - individuella genomförandeplaner - som studeras i artikeln representerar två steg i kontraktualiseringen av äldreomsorgen. I det första steget möter individen den specialiserade biståndshandläggningen och den individuella behovsbedömningen. Detta steg är i många avseenden en välstuderad passage av medborgares inträde i äldreomsorgen (Andersson, 2007a, 2007b; Dunér, 2007; Hellström Muhli, 2003; Lindelöf \& Rönnbäck, 2004; Nordström \& Dunér, 2003; Olaison, 2009). Utfallet av biståndsbedömningen är ett biståndsbeslut. Biståndsbeslutet representerar en utveckling "där allt fler livsområden och företeelser blir rättsligt reglerade [...]" (Johansson, 2011, s. 40). Som Blomberg (2004) samt Blomberg \& Petersson (2011) påpekar, får den specialiserade biståndsbedömningen ofta en grindvaktande funktion som specificerar rätten till insatser och utformar en schabloniserad tidsberäkning för biståndens utförande.

I det andra steget möts den enskilde omsorgspersonalen och de individuella genomförandeplanerna. Inom ramen för genomförandeplanerna ska biståndsbeslutet brytas ned till en konkret och dokumenterad beskrivning av hur den vardagliga hjälpen ska organiseras. Genomförandeplanen ska beskriva biståndets utförande och uttrycka en detaljerad planering av omsorgens upplägg så att en individualisering av omsorgen sker i enlighet med socialtjänstlagen.

\section{Interventions- och implementeringslogikför individuella genomförandeplaner}

Inom den kommun som fungerat som fall (undersökningskommunen) i denna studie är individuella genomförandeplaner ett kommunalpolitiskt fastställt arbetssätt 
i äldreomsorgen. Tankegångarna för hur individuella genomförandeplaner ska fungera och intentionerna för vad de ska uppnå i undersökningskommunen har här sammanfattats med hjälp av en något modifierad variant av Frechtlings (2007) interventionslogiska steg-modell: Input $\rightarrow$ Förädlande aktivitet $\rightarrow$ Effekt. Sammanfattningen bygger på analyser av policydokument och intervjuer med ledande företrädare för äldreomsorgen i undersökningskommunen.

Inputen till de individuella genomförandeplanerna består av att medborgaren beviljas insatser från äldreomsorgen av kommunens biståndshandläggare. Beviljandet av insatser sker på basis av en bedömning av de individuella hjälpbehoven. I biståndsbeslutet anger biståndshandläggaren att medborgaren har behov av "morgonhjälp", "middagshjälp", "kvällshjälp 1"1, "tvätt", "promenad" etcetera. Biståndsbeslutet skickas sedan till kommunens "utförare", dvs. hemtjänstenheterna. På hemtjänstenheterna utses en eller två kontaktpersoner för medborgaren.

Den Förädlande aktiviteten består av att medborgarens kontaktperson tillsammans med medborgaren, om medborgaren vill detta och medborgarens hälsotillstånd tillåter det, genomförs ett eller flera samtal där medborgarens biståndsbeslut ska konkretiseras. Konkretiseringen innebär att det beviljade biståndet "bryts ned" och i detaljerade ordalag beskriver hur

1 Beteckningen "Kvällshjälp l" är en av flera olika beteckningar, exempelvis "Kvällshjälp 2", som används i undersökningskommunen. medborgarens omsorg ska utföras. Den uttryckliga ambitionen i undersökningskommunens policydokument är att medborgaren under den förädlande aktiviteten ska ges ett "reellt inflytande" över sin omsorg. I de fall där medborgaren inte förmår uttrycka sina behov och sin vilja ska dennes kontaktperson, som har ett särskilt ansvar, träda in i medborgarens ställe och beskriva hur omsorgen vanligtvis genomförs. Den individuella genomförandeplanen ska efter första mötet mellan medborgaren och kontaktpersonen uppdateras "vid behov", till exempel vid förändrat hälsotillstånd, på medborgarens önskemål, eller med högst sex månaders mellanrum.

Effekten som förväntas följa, är dels att ett dokument med en mycket konkretiserad beskrivning av genomförandet av medborgarens beviljade biståndsbeslutet skapas, dels att medborgaren fått en individuell planering av sin omsorg där medborgaren vid tillfället då planen skrivs eller uppdateras får ett reellt inflytande över att bestämma över hur omsorgens utförs. En förväntad effekt är att det reella inflytandet ska motverka att medborgaren anpassas till äldreomsorgen och medföra att äldreomsorgen anpassar sin service till medborgaren. En tredje förväntad effekt är att omsorgen utförs på samma sätt oavsett vilken personal som utför den. Det vill säga att den individuella genomförandeplanen ska skapa en omsorgskontinuitet som är oberoende av personkontinuitet.

Den implementeringslogik som tilllämpats i undersökningskommunens sjuåriga top-down drivna implementeringsprocess har dels bestått av perso- 
nalutbildningar, dels central spridning av checklistor för hur en individuell genomförandeplan ska skrivas, dels central benchmarking av antalet medborgare med genomförandeplaner på hemtjänstenhet. Personalutbildningarna har sett olika ut under årens lopp och har nått en större eller mindre del av omsorgspersonalen. Checklistorna har också sett olika ut och har spridits via olika kanaler till olika hemtjänstenheter. Benchmarkingen har varit konstant under hela implementeringsprocessen och mätt antalet medborgare med en individuell genomförandeplan. Resultatet av benchmarkingen har sammanställts centralt och resulterat i en lista där hemtjänstenheter placerar sig på ett kontinuum mellan högst och lägst andel medborgare med en individuell genomförandeplan. Den bakomliggande tanken med benchmarkinglistan beskrivs ungefär som vad Pawson (2002) benämner som "naming and shaming" där offentliggörande av enskilda enheters grad av måluppfyllelse ska skapa incitament för ökad måluppfyllelse för att undvika offentlig skam.

\section{Studiens syfte och metod}

Syftet med den här studien är att undersöka individuella genomförandeplaner med utgångspunkt $\mathrm{i}$ de intentioner som införandet av dessa planer uttrycker. Utifrån interventionslogiken finns det kopplat till individuella genomförandeplaner intentioner om att via individualiserande och planerande dokument skapa en kontraktualiserad organisering av den vardagliga hjälpen för de medborgare som har stöd från äldreomsorgen. Samtidigt ska dessa dokument - och den omsorg de beskriver - omfattas av den kommunala likabehandlingsprincipen - där olikhet just måste handla om medborgarnas individuella behov och önskemål. Men blir det så? Hur manifesteras de olika intentionerna i genomförandeplanerna?

\section{Studiens design}

Studien har genomförts med en succesivt framväxande "mixed method" design där ett sedan tidigare befintligt empiriskt material av 869 individuella genomförandeplaner analyserats både kvalitativt och kvantitativt. Den kvalitativa analysen är ett tillämpande av Altheides (1987) samt Altheide \& Schneiders (2013) etnografiska innehållsanalys i en netnografisk kontext, dvs. kvalitativ analys av ett digitalt, socialt och kulturellt sammanhang. Analysen har bestått i att jag antagit en hypotetisk roll som utförare (omsorgspersonal) och läst planerna med utgångspunkt i den interventionslogiskt härledda frågeställningen: Skulle jag kunna utföra medborgarens beviljade omsorg utifrån vad som framgår i genomförandeplanen? Efter att ha insett att både materialets omfång och den variationsrikedom jag möttes av var övermäktig för en renodlat kvalitativ analys, utvidgade jag studien till att innefatta en kvantitativ innehållsanalys. Denna har genomförts med utgångspunkt i de variabler som bedömts som möjliga att kvantifiera på ett sätt som ger relevant och tillförlitlig kunskap om praxis $i$ den kontraktualiserade organiseringen av vardagshälpen. 


\section{Undersökningskommun och population}

Undersökningskommunen är en kommun med fler än 100000 invånare. De 869 genomförandeplanerna representerar en totalundersökning av omsorgstagare som har minst 25 timmar beviljad hemtjänst per månad inom den undersökta kommunen. Hemtjänsten bedrivs uteslutande i kommunal regi och är organiserad i 30 hemtjänstenheter. Fördelningen mellan könen är 626 kvinnor (72 \%) och 244 män (28\%). Antalet individuella genomförandeplaner per hemtjänstenhet sträcker sig från 9 till 67. Antalet beviljade hemtjänsttimmar per månad sträcker sig mellan 25 till 557 där det finns en viss koncentration runt medelvärdet som är på 82 tim/mån. Medelålder är 83 år och variationsvidden sträcker sig mellan 38 till 104 år.

\section{Datainsamling och variableri studien}

Insamlingen av empiriskt material genomfördes via undersökningskommunens ITbaserade dokumentationssystem. Insamlingen utgick från att jag som forskare gavs tillgång till samma information som var tillgänglig för omsorgspersonalen i undersökningskommunen. Vid insamlingen samlades all tillgänglig information, med hänseende till krav om att avidentifiera samtliga personuppgifter, in. Den information som var tillgänglig kan delas in $\mathrm{i}$ standardiserad respektive en ostandardiserad information. Standardiserad information avser sådan information som inte kunde påverkas av omsorgspersonalen och som utgjorde en sorts ingångsvärden (oberoende variabler) för de individuella genomförandeplanerna. Exempelvis medborgarens personuppgifter, det beviljade biståndet samt tillhörigheten till en specifik hemtjänstenhet.

Den ostandardiserade informationen kunde påverkas av omsorgspersonalen och utgör en del (beroende variabler) av de individuella genomförandeplanerna. Exempelvis information om vem som skrivit den individuella genomförandeplanen, vilka som närvarat vid upprättandet, om genomförandeplanen följts upp efter att den skrevs första gången, vilka av de beviljade omsorgsinsatserna som beskrevs i den individuella genomförandeplanen etcetera. Medan den standardiserade informationen gick att operationalisera fanns det oklarheter som försvårade kvantifieringen av den ostandardiserade informationen. Det gick till exempel inte med säkerhet att avgöra om "Maria" som skrivit 2 genomförandeplaner är samma eller en annan person än "Maria H" som skrivit 3 genomförandeplaner. Då så väl validiteten som reliabiliteten kan anses låg för delar av den ostandardiserade informationen har operationaliseringen begränsats till de variabler som återges i figur 1 .

De oberoende variablerna har använts för att jämföra praxis för olika grupperingar inom populationen, exempelvis för att jämföra praxis mellan kön och hemtjänstenheter. De beroende variablerna har använts som proxybetonade indikatorer för förekomsten av planeringstänkandet, juridifieringstänkandet och dokumenteringstänkandet i kontraktualiserandet av äldreomsorgens vardagshjälp. Begrep- 
Figur I. Oberoende och beroende variabler i studien

\begin{tabular}{|c|c|c|}
\hline $\begin{array}{l}\text { Variabel } \\
\text { beteckning }\end{array}$ & Oberoende variabler i studien & Avser att mäta \\
\hline A & Kön & Medborgares kön \\
\hline B & Ålder & Medborgarens ålder \\
\hline C & Hemtjänstenhet & $\begin{array}{l}\text { Hemtjänstenhet som utför medborgarens } \\
\text { omsorg }\end{array}$ \\
\hline D & Timmar beviljade hemtjänstinsatser & $\begin{array}{l}\text { Medborgarens antal timmar beviljad hemtjänst } \\
\text { per månad }\end{array}$ \\
\hline $\begin{array}{l}\text { Indikator } \\
\text { nummer }\end{array}$ & Beroende variabler i studien & Avser att mäta \\
\hline I & $\begin{array}{l}\text { Grad av tidsangivelser i IGP för när } \\
\text { omsorgsinsatserna ska utföras }\end{array}$ & $\begin{array}{l}\text { Planeringstänkande: I vilken mån IGP innehåller } \\
\text { preciserade tidpunkter för omsorgsinsatsers } \\
\text { genomförande }\end{array}$ \\
\hline 2 & $\begin{array}{l}\text { Andel av de beviljade insatser som tas } \\
\text { med och beskrivs i IGP }\end{array}$ & $\begin{array}{l}\text { Juridifieringstänkande: I vilken utsträckning de } \\
\text { insatser som medborgaren beviljats ingår och } \\
\text { konkretiseras i IGP }\end{array}$ \\
\hline 3 & Antalet ord i IGP & $\begin{array}{l}\text { Dokumenteringstänkande: Hur många ord } \\
\text { som används för att beskriva genomförandet } \\
\text { av medborgarens beviljade omsorgsinsatser } \\
\text { (proxymått för detaljeringsgrad) }\end{array}$ \\
\hline
\end{tabular}

pet "proxy" (eller proximal) avser i detta sammanhang variabler och variabelvärden som kan ses som uttryck för ett visst fenomen och utgör alltså ett försök att operationalisera de tre tankesätt som undersöks. Exempelvis tolkas förekomsten av klockslag som en indikator på om tidsangivelser är en form av planeringstänkande (se vidare figur 1).

Ingen av de tre indikatorerna är ömsesidigt uteslutande och ska inte heller förstås som att de fångar respektive "tänkande" på ett fullödigt sätt. Istället är de som ovan framhållits just proxymått som använts för att hantera det empiriska materialets variationsrikedom. Indikatorn 1 har operationaliserats så att tid kategoriseras i tre kategorier. Dels en kategori där exakta klockslag för genomförandet av medborgarens insatser anges för mer än $80 \%$ av insatserna (exempelvis "Morgonhjälp 07.40'), dels en kategori där enstaka klockslag för genomförandet av insatserna anges, dels en kategori där klockslag inte förekommer, utan insatserna anges som "Morgonhjälp" utan specificerad tidpunkt för genomförandet. Indikator 2 har operationaliserats i fem kategorier. Kategorierna är indelade efter den procentuella andel av medborgarens beviljade bistånd 
som tas med och konkretiseras i genomförandeplanen. Den procentuella indelningen som gjorts utgår från kategorierna 0-40 \%, 41-60\%, 61-80\%, mer än 80\% samt en kategori där det är svårt att bedöma/ svårt att utläsa vilka insatser som tas med och konkretiseras. En bedömningsfråga för indikator 2 har varit om enbart omnämnandet av en beviljad omsorgsinsats, exempelvis "Kvällshjälp l", ska räknas som att biståndet konkretiseras i genomförandeplanen. Då det rimligen bör finnas något innehåll i en omsorgsinsats som kvällshjälp har bedömningen landat $i$ att enbart ett omnämnande av en beviljad insats inte innebär att genomförandet konkretiserats i genomförandeplanen. Indikator 3 är ett proximalt mått på hur utförligt, dvs. hur många ord, som i genomsnitt ägnas åt att beskriva hur genomförandet av medborgarens omsorg ska gå till. Till skillnad från de två övriga indikatorerna som mäter frekvenser i populationen, utgår indikator 3 från hypotesen om att dokumenteringstänkandets betydelse i omsorgsarbetet, med förbehåll för viss individuell variation, bör manifesteras i en ganska påtaglig samvariation mellan antalet beviljade timmar med omsorgsinsatser och det antal ord som används i IGP.

\section{Resultat och Analys}

\section{Om nödvändigheten att tolka det skrivna ordet}

Under genomläsningen av de 869 genomförandeplanerna gavs flera exempel på vad som skulle kunna tolkas som en närvaro och ett uttryck av såväl indi- vidualiserings-, juridifierings-, planerings- och dokumenteringstänkande i den kontraktualiserade organiseringen av vardagshjälpen. Det var emellertid själva tolkandet som med nödvändighet intog huvudrollen då jag försökte förstå materialet genom frågeställningen: Skulle jag kunna utföra medborgarens beviljade omsorg utifrån vad som framgår i genomförandeplanen? Tolkandet framstod som nödvändigt då jag inte kunde undgå att fråga mig om genomförandeplanen som sade åt mig att dela ut 13 cigaretter på måndagar, för att på onsdag dela ut ytterligare 13 cigaretter, var ett uttryck för en långtgående individualisering, en överenskommen planering eller något annat. Skulle jag blint lyda dokumentets ordalydelse eller skulle jag, om jag befunnit mig i den faktiska omsorgssituationen, valt att räcka över ett helt cigarettpaket på måndagen om medborgaren bett om det? Ett annat exempel var att jag gång på gång ställdes inför att göra en tolkning om insatsens "morgonhjälp" kunde utföras närsomhelst under den del av dygnet som jag ansåg tillhöra morgonen eller om det kanske fanns någon underförstådd innebörd i benämningen "Morgonhjälp". I vissa genomförandeplaner specificerade klockslaget för morgonhjälpen, exempelvis klockan 07.30, i andra klockan 08.30 för att i ytterligare andra utelämna klockslag. Detsamma gällde för när jag ställdes inför att genomföra den varken tids- eller innehållsspecificerade insatsen "Kvällshjälp l" vilken jag kunde ana mig till betydde något annat än insatsen "Kvällshjälp 2". I andra genomförandeplaner, som "Evas" som exemplifieras nedan, stod jag 
inför uppgiften att genomföra tre femtedelar av Evas beviljade bistånd, medan det inte framgick om de två resterande femtedelarna av det beviljade biståndet skulle utföras. Eva, som är en kvinna född 1916, har 69 timmar beviljade hemtjänstinsatser per månad och får sina hemtjänstinsatser utförda av hemtjänstenhet A. Insatserna som Eva är beviljad är Morgonhjälp, Förmiddagstillsyn, Lunchhjälp, Matdistribution, Eftermiddagshjälp, Kvällshjälp 2, Natthjälp, Inköp, Ärenden, Städning, Tvätt, Bad/Dusch och Träning. Genomförandet av Evas beviljade hemtjänstinsatser beskrivs med 299 ord. Evas genomförandeplan har i den kvantitativa analysen kodats som att den beskriver 41-61\% av Evas beviljade hemtjänstinsatser och att den anger enstaka klockslag för när omsorgsinsatser ska genomföras:

Morgonhjälp: EVA vaknar tidigt och vill gärna att man kommer tidigt. Man hjälper till att hissa upp huvudändan av sängen så klarar hon själv att ta sig upp ur sängen. Hjälp med att tvätta nedre hygien resten klarar EVA själv, kolla ljumskarna, hjälp med påklädning. Frukost består av gröt eller fil, ev kaffe och smörgås, medicin. Bädda sängen. Se alltid till att EVA har något att dricka där hon sitter och någon frukt.

Dusch: EVA duschar lgång i veckan, hjälp med att tvätta håret och kroppen, se till att hon har en liten handduk som hon har för ansiktet, vill inte få så mycket vatten i ansiktet. Smörja in EVA. Rulla upp håret.
Fm Tillsyn: ca 10:00Toabesök

Middagshjälp: EVA tar mat ifrån oss några gånger i veckan, då hon äter halva portionen och andra halvan till nästa dag. Man hjälper EVA med att lägga upp mat eller värma mat. Fråga vad hon vill ha att dricka. Dom dagar hon inte har mat äter hon något ifrån frysen eller varma koppen. Toabesök.

Emtillsyn: EVA gillar om man sitter en stund och fikar och när vädret tillåter att få gå ut en stund. Hon har medicin kl. 17 som man ställer på bordet i en liten kopp där hon sitter, så tar hon den själv.

Kvällshjälp: Man hjälper EVA att klä av sig, ta på nattlinne, hjälp på toa, medicin. Se till att hon har larmet i närheten och att klockradion står rätt så hon ser vad klockan är. Värm vetekudde i mikron som hon har på fötterna eller ta på strumpor, fråga EVA. Se till att en liten lampa lyser.

Tvätt: 14/dag eller efter behov

Städ: dammsuga, torka golv, damma, torka av i köket, badrum.

Promenad lgång i veckan när vädret tillåter, det är viktigt att EVA får röra på sig. (Hemtjänstenhet A11)

Evas genomförandeplan ger en viss vägledning för när, vad och hur som ska göras samtidigt som formuleringar som "vill gärna att man ska kommer tidigt" lämnar 
ett visst utrymme för tolkning - Vad är "tidigt" i Evas respektive omsorgspersonalens värld? I "Adams" genomförandeplan, som exemplifieras nedan, växer tolkningsutrymmet. Adam, som är en man född 1918, får sina 203 timmar beviljade hemtjänstinsatser utförda av hemtjänstenhet R. Insatserna som Adam är beviljad är Förmiddagstillsyn, Ärenden, Ledsagning, Morgonhjälp, Förmiddagshjälp, Matdistribution, Eftermiddagshjälp, Kvällshjälp 1, Kvällshjälp 2, Natthjälp, Inköp, Städning, Tvätt och Bad/dusch. Genomförandet av Adams beviljade hemtjänstinsatser beskrivs med 35 ord. Adams genomförandeplan har kodats som att den beskriver 0-40\% av Adams beviljade hemtjänstinsatser och att den inte anger några klockslag eller andra tidsangivelser för när Adams omsorgsinsatser ska genomföras:

ADAM har en katt som han är väldigt fäst vid.

ADAM behöver hjälp med personlig omvårdnad för att klara sig bra i hemmet.

ADAM känner trygghet i att vi följer med honom på div läkarbesök. (Hemtjänstenhet R2)

Att Adams genomförandeplan lämnar ett stort tolkningsutrymme och utgör en kontrast till Evas genomförandeplan är uppenbart utifrån den påtagliga skillnaden mellan antalet ord som används för att beskriva Evas 69 timmar (299 ord) kontra Adams 203 timmar (35 ord) beviljade hemtjänstinsatser. Vid sidan av den kontrast som framträder mellan de två exempels omfattning finns också skillnader i karaktär där Evas genomförandeplan har en explicit rubrikstruktur som byggs upp utifrån några av de beviljade hemtjänstinsatserna. Evas genomförandeplan fokuserar på att beskriva genomförandet av insatserna och skulle kunna liknas vid en arbetsbeskrivning för genomförandet av Evas omsorgsinsatser. Adams genomförandeplan har som kontrast ett något oklart fokus där Adams behov av konkreta omsorgsinsatser i stort utelämnas och istället lyfter fram att katten är mycket betydelsefull i Adams liv.

\section{Variation $i$ innehaill och disposition}

Medan Evas genomförandeplan både har ett innehåll och en disposition som skulle kunna ses som ett försök att fokusera på genomförandet av Evas omsorg, är det mer oklart vad som är syftet med innehållet och dispositionen av Adams genomförandeplan. På populationsnivå finns ett flertal genomförandeplaner som liknar de två exemplen ovan. Samtidigt ger de två exemplen långt ifrån en fullständig bild av praxis för den kontraktualiserade organiseringen av vardagshjälpen eller för variationen i genomförandeplanernas innehåll och disposition. Som kontraster till ovanstående genomförandeplaner finns i materialet genomförandeplaner vars främsta kännetecken är att de är skrivna som utförliga levnadsberättelser som i liten eller ingen utsträckning beskriver genomförandet av omsorgen. I levnadsberättelserna hamnar istället indi- 
videns tidigare liv i fokus där redogörelser för nätverk och familjerelationer, flyttningshistorik, yrkesval blandas med individen nuvarande och tidigare intressen. Ytterligare andra genomförandeplaner är skrivna i "jag-form" med formuleringar som "Vid morgonhjälpen får jag..." eller "Vid kvällshjälpen vill jag...". Ytterligare andra genomförandeplaner har karaktären av arbetsbeskrivningar med minutiös detaljrikedom där allt från vilket pålägg det ska vara på frukostsmörgåsen till exakta angivelser hur många cigaretter som medborgaren får röka per dag. Ytterligare något fåtal genomförandeplaner är skrivna som en sorts utvärdering av vad medborgaren tycker om hemtjänstens insatser där beskrivningen av insatserna klaras av på ett par rader och kryddas med svårtydda formuleringar som "Tar hellre vin istället för medicin". Ska formuleringar tolkas som hint om att medborgaren har alkoholproblem, som ett tecken på att medborgarens ord och vilja verkligen kommer till uttryck eller som att kontaktpersonen menar att det är bättre att ställa fram vin än att ge medborgaren sin medicin? Andra genomförandeplaner består av ett par rader text där det konstateras att medborgaren har ett hjälpbehov och har beviljats omsorgsinsatser.

\section{Likheter i vardagshjälpens organisering}

Om en påtaglig variation är kännetecknande för praxis i innehåll och disposition, är en genomgående likhet i den kontraktualiserade organiseringen av vardagen i samtliga genomförandeplaner att de är skrivna i tidsenheter om en dag. Dagen beskrivs på ett sätt så att den förutsätts upprepa sig dagligen. Det vill säga, har en dag planerats, så har alla årets dagar planerats. Vardag och helgdag åtskiljs inte och i den mån det förekommer utrymme för variation $i$ organiseringen av vardagen $i$ genomförandeplanerna anges det med formuleringar som i regel lyder som i Evas genomförandeplan "Fråga vad hon vill ha att dricka". Uppmaningen att omsorgspersonalen ska fråga medborgaren, förekommer i vissa av genomförandeplanerna. Frågorna berör undantagslöst det lilla i vardagen. Vad ska det vara för dryck till måltiden? Vad ska det vara för pålägg på smörgåsen? Den variation som illustrerats i exemplen ovan framträder även i hur populationens genomförandeplaner fördelar sig på indikator 1 där 95 st. (11 \%) genomförandeplaner innehåller specifika klockslag för när mer än 80 \% omsorgsinsatser ska genomföras. I majoriteten av genomförandeplanerna, 535 st. (62\%), finns inte några specifika tidpunkter angivna för när omsorgsinsatserna ska genomföras, medan det i resterande $239(27,5 \%)$ av genomförandeplanerna förekommer enstaka klockslag för när omsorgsinsatserna ska genomföras. Den kvalitativa analysen av de genomförandeplaner som innehåller specifika klockslag för mer än $80 \%$ av hemtjänstinsatserna leder inte fram till att det, annat än i några enstaka fall, exempelvis för utdelning av medicin, går att utläsa några individuella omständigheter som motiverar att den enskilde medborgarens genomförandeplan av särskilda skäl bör innehålla specificerade tidpunkter för när omsorgsinsat- 


\section{Tabell 2.Täckningsgrad av beviljade bistånd i genomförandeplan}

\begin{tabular}{lccc}
\hline $\begin{array}{l}\text { Täckningsgrad av beviljade } \\
\text { bistånd i genomförandeplan }\end{array}$ & Antal & Fördelning i populationen\% & Kumulativ \% \\
\hline Går ej att utläsa & 180 & 20,7 & 20,7 \\
$0-40 \%$ & 208 & 23,9 & 44,6 \\
$41-60 \%$ & 124 & 14,3 & 58,9 \\
$61-80 \%$ & 148 & 17,0 & 75,9 \\
$81-100 \%$ & 209 & 24,1 & 100,0 \\
\hline Total & 869 & 100,0 &
\end{tabular}

serna ska utföras. Analysen visar också att de 239 genomförandeplaner som innehåller enstaka tidsangivelser, i hög grad gör det på basis av att exempelvis färdtjänsten hämtar vid ett visst klockslag, eller att en specifik tid måste passas i samband med medicinsk åtgärd. De normer som kommer till uttryck runt tid, förekomsten av tid i medborgarnas genomförandeplaner, förefaller alltså främst härröra från medicinska överväganden samt avtalade tider med andra aktörer, än vara ett uttryck för att medborgaren tillåtits individualisera tidpunkterna och planeringen för omsorgens utförande. De 535 genomförandeplaner som hamnar i kategorin: "Inga tidsangivelser i IGP" innehåller tidsangivelser som bygger på en zonindelning av dagen i "Morgonhjälp", "Förmiddagshjälp", "Lunchhjälp", "Kvällshjälp" och så vidare. Vad benämningen "Morgonhjälp" innebär i termer av klocktid framgår inte av genomförandeplanerna, men förefaller utifrån de genomförandeplaner som innehåller tidsangivelser betyda att omsorgsinsatsen utförs någon gång mellan 07.00 till ca 09.30 på morgonen.
Variationen i praxis mellan olika genomförandeplaner visar sig också i fördelning på indikator 2 (Andel av de beviljade insatser som tas med och beskrivs i IGP). Som framgår av tabell 2 nedan, innehåller 512 (nästan $59 \%$ ) av genomförandeplanerna i populationen konkretiseringar av mellan 0-60 \% av de omsorgsinsatser som medborgaren enligt biståndet har rätt till att få utfört. I resterande 359 (41 $\%$ ) av genomförandeplanerna i populationen konkretiseras medborgarens beviljade omsorgsinsatser mellan 61-100\%.

I en uppföljande kvalitativ analys av genomförandeplaner som placerar sig $i$ någon av de två yttre kategorierna $0-40 \%$ respektive $81-100 \%$ framträder inte några uppenbara mönster annat än att planer som innehåller 81-100 \% konkretiseringar av det beviljade biståndet av givna skäl har ett fokus på genomförandet av omsorgen.

För indikator 3 (Antalet ord i IGP), som analyserats utifrån hypotesen att fler beviljade hemtjänst timmar bör kräva ett mer omfattande antal ord, är korrelationen, 302 och $\mathrm{R}^{2}=, 091$ ( $\left.p, 000\right)$. Då extremvärden plockas bort utifrån 10:e 
Tabell 3.Andel av det beviljade biståndet som beskrivs i genomförandeplaner tillhörande män respektive kvinnor.

\begin{tabular}{lccc|}
\hline $\begin{array}{l}\text { Procentuell andel av med- } \\
\text { borgarens beviljade bistånd } \\
\text { som berörs i den individuella } \\
\text { genomförandeplanen }\end{array}$ & Kvinna (\%) & Man (\%) & Total \\
\hline Går ej att utläsa & 20,0 & 22,6 & 20,7 \\
$0-40 \%$ & 26,8 & 16,5 & 23,9 \\
$41-60 \%$ & 13,7 & 15,6 & 14,3 \\
$61-80 \%$ & 17,1 & 16,9 & 17,0 \\
$81-100 \%$ & 22,4 & 28,4 & 24,1 \\
\hline Totalt & 100,0 & 100,0 & 100,0
\end{tabular}

percentilen (färre än 36 ord/IGP) respektive 90:e (fler än 298 ord/IGP) percentilen sjunker korrelationen till,185 och $\mathrm{R}^{2}$ till ,033. Samvariationen och prediktionsförmågan mellan antalet beviljade timmar och antalet ord (grad av detaljerade beskrivningar av biståndens utförande och innehåll) i genomförandeplanen är alltså låg i hela populationen och blir lägre när extremvärden tas bort. Indikator 1, 2 och 3 analyserad i relation till medborgarens ålder, där ökad ålder kan förmodas ha viss korrelation med ett ökat omsorgsbehov, visar alltså inte på någon samvariation eller signifikanta skillnader i populationen.

\section{Kön och olikhet}

Utifrån Eva och Adams individuella genomförandeplaner som presenteras i resultatredovisningens inledning skulle det, eftersom de tillhör medborgare av olika kön, kunna tänkas att skillnaderna beror på att medborgare av olika kön behandlas olika. Korstabulering av könets betydelse för indikator 1 om tidsangivelser, indikerar en i det närmaste perfekt överenstämmelse mellan förväntade och uppmätt fördelning inom respektive kön. Tid fördelas alltså inte olika beroende på medborgares kön. För indikator 3 (Antalet ord i IGP) visar analysen inga signifikanta skillnader runt antalet ord i kvinnors respektive mäns genomförandeplaner. För utfallet på indikator 2 (Andel av de beviljade insatser som tas med och beskrivs i IGP), som illustreras i tabell 3 nedan, finns det en signifikant skillnad $(\mathrm{p}, 021)$ som gäller genomförandeplaner som tillhör medborgare av manligt respektive kvinnligt kön. Skillnaden består i att genomförandeplaner som tillhör män $\mathrm{i}$ högre utsträckning tar med och beskriver genomförandet av det beviljade biståndet än genomförandeplaner som tillhör kvinnor. En analys av de skillnader som påvisas mellan genomförandeplaner för medbor- 
Tabell 4. Exempel på skillnader mellan hemtjänstenheter för grad av tidsangivelser i genomförandeplanen för när omsorgsinsatserna ska utföras

\begin{tabular}{lcccc}
\hline \multicolumn{4}{c}{ I vilken mån IGP innehåler preciserade tidpunkter för omsorgsinsatsers } \\
genomförande \\
Hemtjänstenhet & $\begin{array}{c}\text { Inga tids- } \\
\text { angivelser (\%) }\end{array}$ & $\begin{array}{c}\text { Enstaka tids- } \\
\text { angivelser (\%) }\end{array}$ & $\begin{array}{c}\text { Tidsangivelser på } \\
>80 \%(\%)\end{array}$ & Total \\
\hline Enhet D & 65,0 & 30,0 & 5,0 & 100,0 \\
Enhet Q & 66,7 & 33,3 & 0,0 & 100,0 \\
Enhet $\mathrm{R}$ & 2,8 & 97,2 & 0,0 & 100,0 \\
Enhet $W$ & 0,0 & 92,9 & 7,1 & 100,0 \\
Enhet $\mathrm{K}$ & 30,0 & 40,0 & 30,0 & 100,0 \\
Enhet $\mathrm{X}$ & 23,5 & 29,4 & 47,1 & 100,0 \\
Enhet BB & 42,9 & 38,1 & 19,0 & 100,0 \\
Enhet $\ddot{\mathrm{A}}$ & 36,5 & 38,5 & 25,0 & 100,0
\end{tabular}

gare av kvinnligt respektive manligt kön har inte gjorts i denna studie.

\section{Arbetsenhet och olikhet}

Vilken av de 30 hemtjänstenheter som upprättar genomförandeplanen har en signifikant $(p, 000)$ betydelse för i vilken utsträckning överenskommelserna innehåller, respektive inte innehåller klockslag (indikator 1) för när omsorgsinsatserna utförs. Utifrån tabell 4 nedan redovisas hur populationens extremvärden fördelare sig på indikator 1 .

Som framgår av tabellen representerar hemtjänstenhet D och Q en sorts extremvärden i hemtjänstenhetspopulationen genom att i jämförelse med övriga hemtjänstenheter upprätta genomförandeplaner som i cirka 6 fall av 10 inte innehåller några tidsangivelser. Hemtjänstenhet $\mathrm{R}$ och W utmärker sig istället genom att det i mer än 9 fall av 10 förekommer enstaka tidsangivelser. Hemtjänstenheterna $\mathrm{K}$ respektive $\mathrm{X}$ har istället en något mer jämn fördelning men utmärker sig gentemot övriga hemtjänstenheter i populationen genom att det i 3 fall av 10 respektive närmare 5 fall av 10 förekommer preciserade tidpunkter för när omsorgsinsatserna utförs i genomförandeplaner som upprättas på hemtjänstenheten. Hemtjänstenheterna med beteckningarna BB och $\ddot{A}$ representerar i sin tur hur den procentuella fördelningen mellan variabelvärdena ser ut inom den hemtjänstenhetspopulationen i stort, där fördelningen på variabelvärdena på indikator 1 är mer utspridd. Ett snarlikt mönster inom hemtjänstenhetspopulationen framträder på indikator 2. För 
Tabell 5. Exempel på skillnader mellan hemtjänstenheter för den procentuella andel av medborgarens beviljade hemtjänstinsatser som konkretiseras i genomförandeplanen

\begin{tabular}{lcccccc}
\hline & \multicolumn{5}{c|}{ Procentuell andel av medborgarens beviljade bistånd som konkretiseras i den } \\
individuella genomförandeplanen
\end{tabular}

indikator 2 går det att göra ett urval av sex hemtjänstenheter som i tabell 5 nedan bildar tre grupperingar i utfallet på indikator 2 (Andel av de beviljade insatser som tas med och beskrivs i IGP).

Av tabell 5 framgår att enhet $B$ och $G$ utmärker sig som extremvärden bland hemtjänstenheterna på indikator 2 genom att genomförandeplanerna som upprättas på dessa hemtjänstenheter i 8 fall av 10 , respektive 10 fall av 10 konkretiserar mellan 0-40 \% av medborgarens beviljade omsorgsinsatser. Hemtjänstenhet $F$ respektive $\mathrm{X}$ utmärker sig i sin tur som extremvärde $i$ andra änden genom att 6 av 10 genomförandeplaner innehåller konkretiseringar av mellan $81-100 \%$ av medborgarens beviljade omsorgsinsatser. Hemtjänstenhet $J$ respektive $M$ representerar i sin tur hur fördelningen på indikator 2 ser ut inom det stora flertalet hemtjänstenheter där det förekommer en spridning mellan de olika variabelvärdena på indikator 2. I likhet med detta mönster framträder i de två tabellerna visar utfallet utifrån analyser runt indikator 3 på signifikanta skillnader $(p, 000)$ mellan olika hemtjänstenheter avseende hur många ord som används i förhållande till antalet beviljade timmar hemtjänst. För det stora flertalet hemtjänstenheter finns dock en betydande spridning även inom enheten.

\section{Lösa kopplingar mellan dokumentationspraxis och omsorgspraxis}

Sammantaget kännetecknas den praxis som framträder över vardagshjälpens organisering i individuella genomförandeplaner av variationsrikedom. Om omsorgens genomförande vore en spegel av det som stod i genomförandeplanen skulle praxis i den utförda omsorgen präglas av extrem olikhet. Detta är emellertid osan- 
nolikt. I så fall skulle Adams 203 timmars beviljade hemtjänst bestå av lite stöd vid omvårdnad och ledsagning fram och tillbaka till läkaren. Vidare skulle de 512 av 869 medborgare som har en genomförandeplan som beskriver mellan 0-60 \% av det beviljade biståndet också få mellan 0-60 $\%$ av det beviljade biståndet utfört. Alltså talar varken resultatet av den kvalitativa eller kvantitativa analysen för att genomförandeplanerna beskriver den utförda omsorgen. Istället visar resultatet på att de individuella genomförandeplanerna uttrycker en dokumentationspraxis som har lösa kopplingar till den den utförda omsorgen (omsorgspraxis). Medan det ligger bortom studiens räckvidd att tala om omsorgspraxis, har studien i väsentliga avseenden berört dokumentationspraxis. Dokumentationspraxis relaterar till men kan, så som jag använder begreppet, samtidigt särskiljs från administrativa idéer. Med administrativa idéer menar jag exempelvis Fayols (1937) administrativa principer eller Webers (1987) tankar om maskinbyråkrati. En annan än så länge inte lika namnkunnig idé är Ferraris (2013) tes om ett dokumenteringstänkande. Ferraris tes är mycket omfattande men en del av den pekar mot en ökande tilltro till och ett behov i det moderna samhället att ordna, att klassificera, att dokumentera stort som smått med en allt mer utpräglad detaljeringsgrad. Det jag benämner som dokumentationspraxis avser den tillämpade delen av administrativa idéer. Det vill säga när idéer likt Hirdmans (2010) planeringstänkande, Johanssons (2011) juridifieringstänkande, Ferraris (2013) dokumenteringstänkande och individuali- seringstänkandet ska omsättas till praktik Johanssons (2006) iakttagelse av att planer på individnivå är ett fenomen som blivit allt vanligare inom olika välfärdsområden och artikelns iakttagelse av de många formerna av planer på individnivå inom äldreomsorgen, får tas som belägg för att ovan nämnda idéer fått en utbredning även inom det sociala arbetet. Omsättandet av administrativa idéer till praktik berör inte bara själva dokumenterandet. Istället förekommer en dokumenteringspraxis både runt vad Prior (2003) benämner som dokumenterandets produktion, innehaill och användning. Med produktion avses de villkor, exempelvis organisatoriska villkor, som formar skrivandet av dokumentet. Med innehåll avses de mönster, den eller snarare de handlingslinjer, som uppträder i dokumenten. Med användning avses vilken funktion/roll dokumentet får efter att det producerats.

\section{Dokumentationspraxisens produktion, innehaill och användning}

Iakttagelsen att det förekommer en dokumentationspraxis jämte en omsorgspraxis skulle kunna ha stannat vid ett konstaterande av att individuella genomförandeplaner är ett löst kopplat element. Att stanna vid ett sådant konstaterande hade emellertid inneburit att frågor om det lösa elementets produktion, innehaill och användning hade lämnats obesvarade. Samtidigt hade undringar om de administrativa idéerna - juridifierings-, planerings-, individualiserings- och dokumenteringstänkande - kapabilitet och 
begränsningar som del i ett försök att kontraktualisera vardagshjälpens organisering med genomförandeplaner också lämnats obearbetade.

Delvis ligger det bortom studiens frågor och bortom studiens empiriska material. Materialet förmår inte att med tillräcklig utförlighet berätta om de villkor som Prior (2003) menar är centrala att studera i samband med produktionen och användningen av dokumentation. Exempelvis ger källmaterialet inga klara besked om exempelvis anhöriga, som visat sig vara betydelsefulla aktörer i medborgares möte med äldreomsorgen (Sand, 2004), varit med eller inte varit med på det möte som ligger till grund för genomförandeplanerna. Inte heller ger studien något besked om vilka resurser med avseende på tid och utbildning som funnits till förfogande eller vilken inställning som omsorgspersonalen hade då genomförandeplanerna skrevs. Medborgarens eget intresse och förmåga att själv hävda sina rättigheter i hur kontrakten över vardagshjälpens organisering ska formuleras, är inte heller kända. I ett avseende är materialets begränsningar också en illustration av dokumenteringstänkandets begränsningar. Detaljer som kan vara väsentliga, inte bara för en forskare utan också för en omsorgspersonal som ska använda dokumentet, har utelämnats i genomförandeplanerna. Trots oklarheterna i materialet går det utifrån den etnografiska innehållsanalysens att skönja fyra tentativa strategier som omsorgspersonalen tycks ha tilllämpat då genomförandeplanerna skrivits. Identifieringen av fyra strategier medför att det inte kan sägas finns en ensam rådande dokumentationspraxis utan att det istället går att tala om flera olika dokumentationspraxis. Dessa fyra olika strategier, undantaget levnadsberättelsen, har använts för att hantera genomförandeplaner som administrativ idé. Strategierna benämns tentativt som återgivandets strategi, de lösa kopplingarnas strategi, standardformuleringens strategi samt detaljeringsstrategin.

Den strategi som benämns som återgivandets strategi, som är den vanligast förekommande i det studerade materialet, består $i$ att de insatser som anges $i$ medborgarens biståndsbeslut, exempelvis "Morgonhjälp", "Kvällshjälp 1", "Städning" etectera, nämns/listas i genomförandeplanen men blir inte föremål för någon närmare beskrivning om när och hur. Resultatet av strategin blir att det som ovan påtalats som tolkningens nödvändighet manifesterar sig övertydligt vid ett försök att använda genomförandeplanen.

Det som betecknas som de lösa kopplingarnas strategi, representerar vad som tycks vara ett medvetet försök att manipulera mätningar av hur många medborgare som har en genomförandeplan, genom att skriva en eller två kortfattade meningar i genomförandeplanen. Resultatet av strategin blir att genomförandeplanen ur administrativ synvinkel och de kontrollmetoder som tillämpas för dess kvalitet, är ändamålsenlig. Vid ett försök att använda genomförandeplanen blir emellertid nödvändigheten att tolka bortom vad som inte finns med i den skrivna texten uppenbart.

Standardformuleringens startegi är en strategi som uppträder i varierande 
utsträckning i hela det empiriska materialet och innebär att olika formuleringar som "Adam vill att..." eller "På morgonen går Adam ut i badrummet...", återkommer i mening efter mening i genomförandeplan efter genomförandeplan. Vid användningen av genomförandeplanen riktas nödvändigheten av tolkningen mot frågan om detta verkligen är ett uttryck för medborgarens vilja eller mer av en standardiserad beskrivning av en rutinartad arbetsuppgift. Kan man utgå från att Adams vilja är det som står i genomförandeplanen och kan man utgå från att den viljan, den vanan är oförändrad från en dag till en annan?

Den fjärde strategin, detaljeringsstrategin, består av de genomförandeplaner där hela eller merparten av medborgarens formellt beviljade bistånd och medborgarens vardagsliv är nedtecknat i minutiösa detaljbeskrivningar. Detaljeringsstrategin har tolkats som ett genuint försök att leva upp till de administrativa idéerna och interventionslogiken. Om strategin användes av all omsorgspersonal skulle skillnaderna mellan genomförandeplaner som uppmärksammats i denna artikel minska. Strategin väcker samtidigt frågor. Vid användning skulle genomförandeplaner skrivna med detaljeringsstrategin ge upphov till en organisering av vardagen som via detaljeringsgraden leder fram till en, på basis av att genomförandeplanerna är skrivna utifrån antagandet om en dag som upprepas om och om igen, en kontraktualisering av vardagen där det är måndag varje dag hela veckan, 365 dagar om året. En omsorg som i det närmaste blir en idealtyp av det löpande band som Szebehely (1995) beskriver. För att und- vika detta framstår nödvändigheten av tolkning vid användning av genomförandeplanen som något centralt för att undivka blind lydnad och mekaniskt agerande efter genomförandeplanens ordalydelse vid utförandet av omsorgen. I situationer då dokument används som styrmedel för det vardagliga omsorgsarbetet finns det alltså anledning till att tvivla på att skrivet ord inte kan anses var dags lag i arbete med människor och att det därför är berättigat att verifiera varje detalj i genomförandeplanen vid varje insats, varje dag.

\section{Avslutande analys och konkluderande undringar}

I den här artikeln har jag betraktat användandet av genomförandeplaner som ett försök att kontraktualisera äldreomsorgens vardagshjälp. Förstådda som ett kontrakt är intentionen med genomförandeplanerna att med hjälp av detaljerad text organisera hjälpbehövande medborgares vardag utefter det principtänkande som finns i administrativa idéer. Studiens resultat visar vidare att genomförandeplanerna resulterar i att praxis i dokumentationen är löst kopplad till praxis i den utförda omsorgen. Studiens resultat ger även uppslag om möjliga strategier och fenomen som förekommer i produktionen, innehållet och användningen av genomförandeplanerna. Dessa strategier och fenomen reser i sin tur ytterligare frågor. Vad är det som gör att en löst kopplad dokumenteringspraxis uppstår? Vad är det som gör att det tycks förekomma olika strategier vid skrivandet av genomförandeplaner? Och vad är det som gör att 
fenomenet om nödvändigheten att tolka, infinner sig $i$ anslutning till användningen av genomförandeplanerna?

\section{Jämförande analys mellan undantagskontrakt och genomförandeplaner}

Några uttömmande svar på frågorna låter sig inte formuleras. Ytterligare tentativa uppslag till varför en löst kopplad dokumenteringspraxis existerar (?) låter sig emellertid formuleras då de administrativa idéerna för genomförandeplaner jämförs med de idéer som fanns kopplade till de överlåtelse- och undantagskontrakt som Gaunt (1996) beskriver. De bakomliggande administrativa idéerna för genomförandeplanerna innebär att juridifierings-, planerings-, individualiserings- och dokumenteringstänkandet men även ett sorts utbytbarhetstänkande, där en personbunden omsorgsrelation ska översättas till och ersättas med en text, försöker träda längre in i och med högre detaljrikedom reglera vardagen än vad som var fallet med överlåtelse- och undantagskontrakt. Överlåtelse- och undantagskontrakten reglerade förhållanden som rättigheten för individen som rörde ekonomiska förhållanden, exempelvis den årliga tilldelningen av tunnor med råg eller antalet kilo fläsk. De administrativa idéerna bakom genomförandeplanerna avser istället att genomförandeplanerna i detalj ska beskriva hur de handlingar som utgör omsorgen ska utföras. I detaljeringsstrategin ger fokuset på precisa och detaljerade beskrivningar av omsorgens utförande upphov till genomförandeplanen som en standard som vid tillämpning skulle innebära en återupprepande dag. Genomförandeplanens bakomliggande intentioner stannar alltså inte vid att konstatera att medborgaren har rätt till vissa fritt disponibla resurser utan försöker tränga in i själva resursens tilldelande, i omsorgshandlingarnas vardagliga utförande. Genomförandeplanerna utgör på så sätt ett mer detaljreglerande kontraktsliggörande av vardagshjälpens organisering än överlåtelse- och undantagskontrakt.

En annan skillnad mellan överlåtelseoch undantagskontrakten och genomförandeplanerna är att de första berörde en högst begränsad andel av befolkningen medan de senare, inom ramen för en annan organiseringsmodell av omsorgen om äldre, på industriell skala söker att kontraktsliggöra vardagshjälpens organisering. Genomförandeplaner berör, som framkommer i Myndigheten för Vårdanalys (2013) kartläggning, med stor sannolikhet långt över 100000 medborgare. Det innebär att, om detaljeringsstrategin skulle tillämpas utbrett, att så väl skrivandet av, men också uppdateringarna så att genomförandeplanernas innehåll är dagsaktuella, skulle ta mycket resurser i anspråk. Dokumentationspraxis och omsorgspraxis riskerar i en resursbegränsad kontext att hamna i konflikt med varandra. Detta reser undringar om vad framväxten av genomförandeplaner som ett löst kopplat element som dokumentationspraxis representerar och hur det relaterar till den återkommande nödvändigheten av att tolka genomförandeplanerna som påtalats ovan. Inte heller här låter sig något uttömmande svar tecknas men jämförelsen med Gaunts (1996) överlåtelse- och undantags- 
kontrakt möjliggör även här ett tentativt svar.

Gaunts (1996) redogörelse för överlåtelse- och undantagskontrakt beskriver långt ifrån kontrakten som något löst kopplat element. Istället redogör Gaunt för att kontrakten användes och att de problem som ibland uppstod vid användningen var att kontrakten var så generösa att det i tider av nöd uppstod svårigheter för den omsorgsgivande parten att leva upp till kontraktets innehåll. Det rådde alltså inte någon svårighet $\mathrm{i}$ att tolka hur kontrakten skulle tillämpas utan istället bestod svårigheten $\mathrm{i}$ att leva upp till kontraktens innehåll. Ett fenomen som återkommit vid läsningen av varje genomförandeplan, oavsett om det är De lösa kopplingarnas strategi eller Detaljeringsstrategin, som kan förmodas ligga bakom genomförandeplanen, är nödvändigheten att tolka. Att nödvändigheten att tolka är återkommande inslag vid läsningen av genomförandeplaner men inte tycks ha varit närvarande vid läsningen av överlåtelse- och undantagskontrakt kan ha att göra med att medan genomförandeplanerna riktar in sig på en detaljreglerad organisering av vardagen medan överlåtelse- och undantagskontrakt rättigheten till mätbara tillgångar på årsbasis.

\section{Kunskapsbehovom dokumenterandets kapabilitet, begränsningar och utbredning}

Den ovan nämnda skillnaderna reser undringar om de fem administrativa idéernas - juridifierings-, planerings-, individualiserings-, utbytbarhets- och doku- menteringstänkande - möjligheter och begränsningar i anslutning till omsorgsarbetet och medborgarens omsorgsbehov. Det tycks utifrån studiens resultat finnas ett sorts generellt reduceringsproblem kopplat till att tillämpa de administrativa idéerna i genomförandeplaner. De tre vanligast förekommande strategierna är alla ett sätt att inte realisera de administrativa idéerna i en detaljerad kontraktualisering av vardagen. Istället är de strategier för att förenkla proceduren eller hantera kravet om genomförandeplaner. Den minoritet av omsorgspersonalen som väljer detaljeringsstrategin ställs istället inför reduceringsproblemet genom att de producerar en mycket detaljerad beskrivning av en vardag som återupprepar sig. Samma reduceringsproblem uppenbarar sig i den variant av genomförandeplaner som benämnts som levnadsberättelser ovan. Delar av medborgarens liv blir föremål för en beskrivning medan andra utelämnas. Att försöka fånga och inordna det komplexa som det sociala, det föränderliga omsorgsbehovet, den vardagliga viljan och den personliga relationen under de administrativa idéer som genomförandeplanerna bygger på, tycks alltså utifrån studiens resultat vara en uppgift som hanterats på högst olika sätt och som alla konfronteras med val om vad som ska tas med och vad som måste tas bort. Att det tycks finnas en svårighet $i$ att fånga allt det väsentliga i genomförandeplanerna reser undringar om vilken möjlighet och vilka begränsningar de individuella genomförandeplanerna har att hantera, en medborgares föränderliga vilja- och omsorgsbehov och ett omsorgsarbete som enligt Törn- 
quist (2004) kräver flexibilitet i sin utövning. Låter sig medborgarens vardagliga vilja och omsorgsbehov och omsorgsarbetets krav på att möta dessa med flexibilitet fångas på ett för de två huvudsakligt inblandade parterna, medborgaren och omsorgspersonalen, meningsfullt sätt inom ramen för genomförandeplaner? Låter sig det Törnquist (2004) och Wærness $(1984,1996)$ beskriver som omsorgsrationalitetens persons- och relationsbundna kunskap och komplexa omsorgsbehov transformeras till en text med en sådan planering och detaljeringsgrad att omsorgskontinuitet oberoende av personkontinuitet uppnås? Är sådan nedtecknad omsorgskontinuitet önskvärd? I vilken grad förhindrar en sådan utförlig dokumentation den normaliserande variation som uppstår genom att ha olika relationer till olika personer ur personalgruppen i olika omsorgssituationer?
I en vidare mening reser jämförelsen mellan bondesamhällets överlåtelse- och undantagskontrakt och välfärdssamhällets nylansering av genomförandeplaner också undringar om vilka andra administrativa idéer och andra drivkrafter som underbyggt den utbredning av planer på individnivå inom det sociala arbetet som Johansson (2006) pekar på. Johanssons påpekande om dokumenteringstänkandets utbredning, Moréns (1999) sonderande artikel om dokumentationens roll i det sociala arbetet och den jämförande analysen i denna studie pekar i en vidare bemärkelse även på att det finns en idéhistorisk kunskapslucka runt en av det sociala arbetets, visserligen ofta löst kopplade, men samtidigt mest utbredda och inrotade institutioner, dokumentationen, och hur dokumentation använts eller inte använts för att försöka styra organiseringen av vardagen $i$ äldreomsorgen. 


\section{Referenser}

Altheide, D. L. (1987). Etnographic Content Analysis. Qualitative Sociology, 1(10), 65-77.

Altheide, D. L. \& Schneider, C. J. (2013). Qualitative media analysis. Thousand Oaks: SAGE.

Andersson, K. (2007a). Myndighetsutövning i äldreomsorgen - Att skapa likhet i äldres behov. I S. Johansson (Red.), Social omsorg i socialt arbete (s. 152-172). Malmö: Gleerups Utbildning $\mathrm{AB}$.

Andersson, K. (2007b). Omsorg under förhandling - om tid, behov och kön i en föränderlig hemtjänstverksamhet. (avhandling för doktorsexamen, Umeå universitet).

Barker, E. (1960). Social contract. London: Oxford University Press.

Blomberg, S. (2004). Specialiserad biståndshandläggning inom den kommunala äldreomsorgen. (avhandling för doktorsexamen, Lunds universitet).

Blomberg, S. \& Petersson, J. (2010). Äldreomsorgens omvandling. I S. Johansson (Red.), Omsorg och mångfald (s. 132-147). Malmö: Gleerup.

Blomberg, S. \& Petersson, J. (2011). När en ny organisationsmodell blir vardag - spridning av specialiserad biståndshandläggning inom den kommunala äldreomsorgen och vad som hände sedan. Socionomen, Forsknings Supplement, (29), 20-32.

Dunér, A. (2007). To maintain control: Negotiations in the everyday life of older people who can no longer manage on their own. (avhandling för doktorsexamen, Göteborgs universitet).

Fayol, H. (1937). Administrative theory in the state. In L. Gulick \& L. Urwick (Red.), Paper on the science of administration. (s. 101-114). New York: Institution of Public Administration, Columbia University.

Frechtling, J. A. (2007). Logic modeling methods in program evaluation. San Francisco: Jossey-Bass.

Gaunt, D. (1996). Familjeliv i Norden (2:a upplagan). Stockholm: Gidlunds.

Hellström Muhli, U. (2003). Att överbrygga per- spektiv: en studie av behovsbedömningssamtal inom äldreinriktat socialt arbete. (avhandling för doktorsexamen, Göteborgs universitet).

Hirdman, Y. (2010). Att lägga livet tillrätta: studier $i$ svensk folkhemspolitik (4:e upplagan). Stockholm: Carlsson.

Hjalmarson,I. (2006). MANSÖKER INTE HJÄLP I ONÖDAN... - Utvärdering av ett projekt med förenklad biståndsprövning av hemtjänst $i$ Hägersten och Norrmalm i Stockholm (Rapport nr 2006:1). Stockholm: Stiftelsen Stockholms läns äldrecentrum.

Johansson, H. (2006). Individuell handlingsplan. I V. Denvall \& B. Vinnerljung (Red.), Nytta \& Fördärv - Socialt arbete i kritisk belysning (s. 131-168). Stockholm: Natur \& Kultur.

Johansson, S. (2011). Juridifiering som institutionell förändring. Om mötet mellan straffrätt och socialrätt vid interorganisatorisk samverkan. RETF/ERD. Nordic Journal of Law and Justice, 34(135), 38-59.

Lindelöf, M., \& Rönnbäck, E. (2004). Att fördela bistånd-Om handläggningsprocessen inomäldreomsorgen. (avhandling för doktorsexamen, Umeå universitet).

Löfström, C. (2007). Framtidens hemtjänst? Om valfrihet/inflytande, förenklad biståndsbedömning och nya yrkesroller. Göteborg: FoU i Väst.

Meagher, G. \& Szebehely, M. (2013). Marketisation in Nordic eldercare: A research report on legislation, oversight, extent and consequences (Stockholm studies in social work nr 30). Stockholm: Stockholms Universitet.

Morén, S. (1999). Dokumentationens roll i socialt arbete - Perspektiv och utvecklingsmöjligheter. Socialvetenskaplig Tidskrift,(4), 329-342.

Myndigheten för Vårdanalys. (2013). Kartläggning av kommunernas arbetssätt för förenklad hantering och ökad flexibilitet $i$ hemtjänsten. Stockholm.

Nordström, M., \& Dunér, A. (2003). Bevilja och ta emot hjälp - Om biståndsbedömare och äldre $i$

David Hedlund: Vardagens kontraktualisering. 
kommunal äldreomsorg. (Rapport nr 2003:5). Göteborg: Göteborgsregionens kommunalförbund och FoU i Väst.

Olaison, A. (2009). Negotiating needs Processing older persons as home care recipients in gerontological social work practices. (avhandling för doktorsexamen,Linköpings universitet).

Pawson, R. (2002). Evidence and Policy and Naming and Shaming. Policy Studies, 23(3), 211-230.

Prior, L. (2003). Using documents in social research. London: Sage.

Prop. 2009/10:116. Värdigt liv iäldreomsorgen.

Renström Törnblom, M. (1988). Att Dokumentera - Hinder eller hjälp $i$ socialt arbete? (FoU-rapport nr 88). Stockholm: Socialtjänsten, Forsknings- och utvecklingsbyrån, Stockholms stad.

Sand, A-B. (2004). Förändrad tillämpning av offentlig äldreomsorg-ett hot mot målsättningen om demokrati och jämställdhet? Socialvetenskaplig Tidskrift, (3-4), 293-309.

Socialstyrelsen (2010). Handläggning och dokumentation inom socialtjänsten. Stockholm: Socialstyrelsen.

Socialstyrelsen (2013). Kommun- och enhetsundersökningen, vård och omsorg om äldre, 2012 underlag till öppna jämförelser och Äldreguiden 2013. Stockholm.

Socialstyrelsen (2014). Äldre och personer med funktionsnedsättning - regiform år 2013. Vissa kommunala insatser enligt socialtjänstlagen. Stockholm.
Socialstyrelsen (2014). SOSFS 2014:5 - Dokumentation i verksamhet som bedrivs med stöd av SoL , LVU , LVM och LSS. Socialstyrelsens författningssamling.

Socialstyrelsen (2006). SOSFS 2006:5 - Socialstyrelsens föreskrifter och allmänna råd om dokumentation vid handläggning av ärenden och genomförande av insatser enligt SoL, $L V U$ , LVM och LSS. Stockholm.

SOU 1997:170. Bemötande av äldre.

SOU 2008:51. Värdigt livi ialdreomsorgen.

Szebehely, M. (1995). Vardagens organisering: Om vårdbiträden och gamla i hemtjänsten. (avhandling för doktorsexamen, Lunds universitet). Lund: Arkiv Förlag.

Törnquist, A. (2004). Vad man ska kunna och hur man ska vara: en studie om enhetschefers och vårdbiträdens yrkeskompetens inom äldreomsorgens särskilda boendeformer. (avhandling för doktorsexamen, Stockholms universitet). Stockholm: HLS förlag.

Wærness, K. (1984). The Rationality of Caring. Economic and Industrial Democracy, 5(2), 185-211.

- (1996). "Omsorgsrationalitet": Reflexioner över ett begrepps karriär. I R. Eliasson (Red.), Omsorgens skiftningar: Begreppet, vardagen, politiken, forskningen (s. 203-220). Lund: Studentlitteratur.

Weber, M. (1987). Ekonomi och samhälle: Förståendesociologins grunder 3 [Politisk sociologi]. (A. Lundquist \& J. Retzlaff, Red.). Lund:Argos. 


\section{Summary}

\section{On intentions and practice in individual care plans in eldercare}

The aim of the study has been to theorize and investigate the phenomenon of individual plans in eldercare. The article uses a literature-based historical outlook and empirical data in order to study the underlying intentions and practice in the type of individual care plans that are used in contemporary eldercare. The main empirical material consisting of 869 individual care plans was collected and analysed through a mixed method design of qualitative and quantitative content analysis. A review of the literature reveals that individual plans have been used in several societal contexts to organize the care of the elderly but this is scarcely highlighted in the research. It is also evident that individual plans in all of the societal contexts have features of a planning, juridical and documenting contract between the individual and the care provider that is similar to the idea of a societal contract. Perceived as societal contract, the contemporary form of individual care plans is revealed as a practice that is highly varied. It is concluded that the underlying intentions of the individual care plans attempt to contract the organization of care in everyday life but that the practice expressed in the plans is a loosely coupled element not corresponding to the practice in the actual care. It is further concluded that further study is needed of the underlying administrative ideational intentions and the capabilities and limitations they constitute for documents in social work. 